\title{
Cara Memilih Bisnis Sampingan Yang Tepat Bagi Guru-Guru SMP Al-Islah Surabaya
}

\author{
Riyan Sisiawan Putra ${ }^{1}$ \\ Ubaidillah Zuhdi ${ }^{2}$ \\ Universitas Nahdlatul Ulama Surabaya ${ }^{1,2}$ \\ Email : riyan_sisiawan@unusa.ac.id
}

\begin{tabular}{l} 
Akuntansi Bisnis dan \\
Manajemen (ABM), \\
\hline Volume 7 \\
Nomor 2 \\
Halaman 1-8 \\
Bulan Desember, \\
Tahun 2020 \\
ISSN 2477-6432 \\
E-ISSN 2721-141X
\end{tabular}

Informasi Artikel

Tanggal Masuk:

1 Nov 2020

Tanggal Revisi:

11 Nov 2020

Tanggal Diterima:

22 Nov 2020

\section{Abstract}

The community service conducted in SMP Al-Islah Surabaya and the participants were coming from the teachers of SMP Al-Islah Surabaya itself. The teachers are approximately consists of 30 people. The teachers monthly salary are mostly only limited to fulfill their basic necessities hence having a side business to support the main income would contribute in fulfilling other needs, while also able to lead their students. Therefore there will be no thoughts to do bad deeds when they could not fulfill their daily needs. Besides inspiring and motivating the students, they are expected to be more excited in realizing the business idea. The community service method consists of three phases. Preparation phase, Implementation phase, and the last one, Activity Report of community service. The expected outcome from this community service of SMP Al-Islah Surabaya teachers is the increasing understanding towards the benefits of side business. This can be seen when the teachers are enthusiastic towards the service. After the community service is done, the teachers are expected to create and establish their own business.

Keywords: Side business; Business idea; Motivation

\begin{abstract}
Abstrak
Kegiatan pengabdian kepada masyarakat ini dilaksanakan di gedung SMP Al-Islah Surabaya dan peserta kegiatan pengabdian kepada masyarakat ini dari Guru-guru SMP Al-Islah Surabaya. Guru-guru pada SMP Al-Islah Surabaya kurang lebih 30 Guru. Kita mengetahui gaji seorang Guru itu tidaklah besar oleh sebab itu bila memiliki bisnis sampingan akan sangat membantu sekali dalam memenuhi kebutuhan sehari-hari, sekaligus bisa membimbing siswanya secara nyata. Sehingga tidak terpikirkan untuk melakukan perbuatan buruk ketika gaji Guru tersebut tidak bisa memenuhi kebutuhan sehari-harinya. Selain memberikan inspirasi dan motivasi diharapkan Guru-guru bisa lebih bersemangat dalam mewujudkan ide-ide bisnisnya. Metode pelaksanaan kegiatan pengabdian kepada masyarakat ini terdiri dari tiga tahap. Pertama tahap pesiapan, tahap kedua yaitu tahap pelaksanaan program, dan tahap terakhir adalah pelaporan hasil kegiatan pengabdian kepada masyarakat. Hasil yang diharapkan dari kegiatan pengabdian masyarakat pada guru-guru SMP Al-Islah Surabaya yaitu meningkatnya pemahaman para Guru tentang bisnis sampingan dan manfaat-manfaatnya. Hal ini dapat dilihat ketika para guru sangat berantusias pada kegiatan pengabdian kepada masyarakat ini Setelah kegiatan pengabdian masyarakat ini selesai, Guru-guru bisa termotivasi untuk membuka/merintis usaha sampingan, dan mewujudkan ide-idenya secara nyata.
\end{abstract}

Kata Kunci : Bisnis Sampingan, Ide Bisnis, Motivasi

\section{PENDAHULUAN}

Kegiatan pengabdian kepada masyarakat ini dilaksanakan di gedung SMP Al-Islah Surabaya dan peserta kegiatan pengabdian kepada masyarakat ini berasal dari Guru-guru SMP Al-Islah Surabaya itu sendiri. Lokasi SMP Al-Islah Surabaya terletak di Jl. 
Gununganyar Tengah 22, Gunung Anyar, Kec. Gununganyar, Kota Surabaya.Jumlah Guru yang berada di SMP Al-Islah Surabaya kurang lebih ada 30 Guru. Mereka mengajar para siswanya sesuai dengan bidangnya masing-masing. Banyak guru yang menggantungkan penghasilan ekonomi mereka dengan mengajar para siswanyaa dari pagi sampai sore. Bahkan bisa diketahui bahwa gaji seorang Guru itu tidaklah besar terutama guru honorer. Meskipun profesi sebagai guru merupakan pekerjaan mulia dan dibanggakan, banyak guruguru yang mempunyai permasalahan dimana tingkat penghasilan mereka tidaklah menentu sehingga hal ini akan turut mempengaruhi tingkat kesejahteraan perekonomian para guru. Melihat dari berbagai kacamata sosial dimana penghasilan seorang guru terkadang tidak mencukupi untuk memenuhi kebutuhan sehari-hari dan keluarga mereka, banyak guru yang kebingungan untuk mencari penghasilan tambahan agar bisa memenuhi kebutuhan mereka. Oleh sebab itu hal lain yang bisa dimanfaatkan oleh para guru untuk meningkatkan perekonomian mereka yaitu dengan berwirausaha atau membuka usaha baru sebagai pekerjaan sampingan, jika seorang guru mempunyai usaha ataupun bisnis sampingan setidaknya dapat menambah penghasilan mereka sendiri sehingga tidak hanya bergantung pada gaji mengajar yang mereka terima setiap bulannya. Dalam hal ini di butuhkan pembinaan dikarenakan supaya lahir usaha kecil - usaha kecil yang di buat oleh para guru, dan kita tau bahwa industry kecil merupakan tulang punggung perekonomian, ini sesuai denganapa yang dikatakan oleh Putra, R. S (2017) Sektor industri kecil memiliki peluang besar sebagai sektor tulang punggung perekonomian.

Ratnasari (2009) mengartikan pekerjaan sampingan adalah sebagai aktivitas yang dilakukan diwaktu luang diluar pekerjaan pokok sebagai kegiatan yang disukai dan dapat memberi kepuasan bagi individu yang bersangkutan. Mempunyai aktivitas yang disenangi dapat memberikan kepuasan selain pekerjaan pokok. Pekerjaan sampingan dapat memberikan kesempatan untuk menunjukkan kompetensi diri, terlibat dalam kegiatan yang berarti dan berinteraksi sosial. Thomas W. Zimmerer (1996;51) mengungkapkan bahwa kewirausahaan merupakan proses penerapan kreativitas dan inovasi untuk memecahkan masalah dan mencari peluang yang dihadapi setiap orang dalam kehidupan sehari-hari. Entrepreneur adalah mereka yang berani mewujudkan ide menjadi kenyataan. Menurut Joseph Schumpeter, Entrepeneur is a person who perceives an oppotunity and creates an organization to pursue it (Bygrave, 1994:2). Sedangkan Scarborough dan Zimmerer dalam Novian (2012) mendefinisikan bahwa seorang wirausaha (entrepreneur) yaitu orang yang menciptakan suatu bisnis baru dalam menghadapi resiko dan ketidakpastian dengan maksud untuk memperoleh keuntungan dan pertumbuhan dengan cara mengenali peluang dan mengkombinasikan sumber-sumber daya yang diperlukan untuk memanfaatkan peluang tersebut.

Ada hubungan dasar antara pemberian motivasi mengenai kewirausahaan dengan pengimplementasian ide-ide bisnis dalam menjalankan usaha sampingan bagi para guru. Menurut Basrowi (2014: 64) faktor-faktor yang mempengaruhi minat berwirausaha yaitu faktor internal dan faktor eksternal. Faktor internal yaitu segenap pikiran emosi dan persoalan dari dalam diri seseorang yang mempengaruhi minat, faktor internal meliputi motivasi, kemampuan, perasaan senang. Sedangkan faktor eksternal adalah faktor yang berasal dari luar diri seseorang yang dapat mempengaruhi minatnya Thomas W.Zimmer et al (2005) merumuskan manfaat berwirausaha sebagai berikut : 1. Memberi peluang dan kebebasan untuk mengendalikan nasib sendiri. 2. Memberi peluang untuk melakukan perubahan. 3. Memberi peluang untuk mencapai potensi diri sepenuhnya. 4. Memiliki peluang untuk meraih keuntungan seoptimal mungkin. 5. Memiliki peluang untuk berperan aktif dalam masyarakat dan mendapatkan pengakuan atas usahanya. 6. Memiliki peluang untuk melakukan sesuatu yang disukai dan menumbuhkan rasa senang dalam mengerjakannya. Sehingga berwirausaha menjadi suatu proses alternatif lain dari pemecahan solusi dari permasalahan yang dihadapai melalui peningkatan inovasi dan 
penerapan kreativitas dari ide yang dimiliki. Seperti yang dikatakan oleh Suhartini (2011), bahwa Berwirausaha dapat memberikan pendapatan yang dapat digunakan untuk memenuhi kebutuhan hidupnya. Keinginan untuk memperoleh pendapatan itulah yang dapat menimbulkan minatnya untuk berwirausaha. Jika seseorang berharap untuk mendapatkan pendapatan yang lebih tinggi dengan menjadi seorang wirausaha, ia akan semakin terdorong untuk menjadi seorang wirausaha..

Membuka usaha sampingan dengan berbisnis menjadi jalan alternatif yang bisa menguntungkan bagi para guu dalam mengatasi permasalahan yang dihadapi. Sama dengan halnya yang dikatakan Putra, R. S (2016) bahwa Pentingnya menjadi seorang pengusaha/entrepreneur adalah karena seseorang bebas dan memiliki kemampuan untuk hidup mandiri dalam menjalankan kegiatan usahanya. Menjadi seorang pengusaha bebas merancang, menentukan, mengelola, dan mengendalikan usahanya. Dengan begitu pentingnya berwirausaha merupakan suatu pemahaman betapa berpengaruhnya penghasilan ekonomi berhubungan dengan kesejahteraan individu. Dengan membuka usaha sampingan akan sangat membantu sekali dalam memenuhi kebutuhan sehari-hari, sekaligus bisa membimbing siswanya secara nyata untuk dapat menjadi seorang entrepreneur juga. Berdasarkan ilustrasi diatas maka, peserta membutuhkan pemahaman mengenai kewirausahaan, bagaimana cara untuk merintis/membuka usaha sampingan yang sesuai dengan minat mereka. Pengabdian masyarakat yang akan dilakukan berfokus mengenai cara memilih bisnis yang tepat bagi Guru-guru SMP Al-Islah Surabaya.

\section{GAMBARAN UMUM MASYARAKAT SASARAN}

SMP Al-Islah merupakan sekolah menengah pertama yang terletak di daerah Gununganyar, Surabaya. Guru yang berada di SMP Al-Islah Surabaya kurang lebih ada 30 Guru. Mereka mengajar para siswanya sesuai dengan bidangnya masing-masing. Banyak guru yang menggantungkan penghasilan ekonomi mereka dengan mengajar para siswanyaa dari pagi sampai sore.

\section{METODE PELAKSANAAN}

Metode pelaksanaan kegiatan pengabdian kepada masyarakat ini terdiri dari tiga tahap. Pertama tahap pesiapan melalui pra-survei, pembentukan tim, pembuatan proposal, koordinasi tim dengan mitra, dan persiapan bahan untuk kegiatan bahan pengabdian kepada masyarakat. Tahap kedua yaitu tahap pelaksanaan program berupa sosialisasi dan pemberian motivasi mengenai kewirausahaan kepada para Guru SMP Al-Islah Surabaya. Sosialisai dilakukan melalui pemaparan materi, tanya jawab dan diskusi. Dan tahap terakhir adalah pelaporan hasil kegiatan pengabdian kepada masyarakat.

\section{PEMBAHASAN}

Kegiatan pengabdian kepada masyarakat tentang kewirausahaan untuk para Guru SMP Al-Islah Surabaya ini dilaksanakan selama satu bulan mulai dari bulan Juli sampai Agustus 2019. Pemateri memberikan materi tentang menumbuhkan jiwa kewirausahaan, bagaimana memulai usaha baru sebagai bisnis sampingan dan memotivasi para Guru SMP Al-Islah Surabaya agar mereka bisa mengimplementasikan ide-ide bisnis yang mereka miliki.

Dengan adanya kegiatan program pengabdian masyarakat bidang kewirausahaan oleh Fakultas Ekonomi dan Bisnis Universitas Nahdlatul Ulama Surabaya ini diharapkan mampu menyelesaikan permasalahan dalam menumbuhkan jiwa kewirausahaan kepada para Guru SMP Al-Islah Surabaya agar bisa meningkatkan perekonomian mereka sendiri dengan membuka usaha sampingan. Karena apabila para guru mengetahui manfaat dari berwirausaha, mereka juga bisa membuka lapangan pekerjaan sendiri, bisa mengurangi pengangguran disekitarnya, dan yang paling penting adalah bisa meningkatkan 
perekonomian mereka sendiri selain dari mengandalkan gaji menjadi seorang guru. Jika kewirausahaan itu berjalan maka perekonomian di daerahnya tersebut juga menjadi produktif.

Pada dasarnya para Guru di SMP Al-Islah Surabaya ini mempunyai banyak ide-ide yang bagus untuk direalisasikan dan memiliki kemauan dalam menambah pengetahuan dan pemahaman kewirausahaan ataupun aplikasi kewirausahaan. Hal ini dapat dilihat ketika Guru-guru ini sangat berantusias pada kegiatan pengabdian masyarakat dan banyak pertanyaan dalam sesi tanya jawab. Para Guru di SMP Al-Islah sendiri banyak yang memiliki kemauan dalam membuka usaha bisnis sampingan agar mereka tidak hanya mengandalkan perekonomian mereka dari gaji menjadi seorang guru saja, akan tetapi juga ingin menjadi seorang entrepreneur yang bisa mengelola usaha dengan baik. Kegiatan pengabdian masyarakat yang dilakukan oleh Fakultas Ekonomi dan Bisni ini di sambut baik oleh peserta dari SMP Al-Islah Surabaya dan mereka juga berharap agar kegiatan ini didakan secara berkelanjutan dengan membuka program seperti pelatihan mengenai kewirausahaan sehingga para peserta bisa mengaplikasikan secara langsung dan dapat merasakan manfaatnya

\section{KESIMPULAN}

Berdasarkan kegiatan yang telah dilaksanakan oleh Tim Pengabdian Kepada masyarakat pada Guru-guru SMP Al-Islah Surabaya dapat disimpulkan bahwa Pertama, kegiatan pengabdian kepada masyarakat mengenai cara memilih bisnis sampingan yang tepat bagi Guru-guru SMP Al-Islah Surabaya berjalan dengan baik sesuai dengan rencana awal. Kedua, kegiatan pengabdiankepada masyarakat pada Guru-guru SMP Al-Islah Surabaya ini berisi tentang pemapamaran materi dan juga pemberian motivasi oleh Tim pengabdian masyarakata yang mana dilanjutkan dengan sesi tanya jawab dan diskusi langsung oleh peserta kepada pemateri, sehingga tidak hanya berbagi ilmu saja akan tetapi juga sharing mengenai permasalahan-permasalahan yang sudah dihadapi. Ketiga, tujuan dari kegiatan yang dilaksanakan untuk memotivasi para Guru SMP Al-Islah Surabaya agar dapat membuka usaha sampingan dan cara memilih usaha yang cocok bagi bisnis mereka.

Keempat, kegiatan pengabdian kepada masyarakat mengenai cara memilih bisnis sampingan yang tepat bagi Guru-guru SMP Al-Islah Surabaya ini memiliki kontribusi dan manfaat yang besar besar bagi mereka sendiri dan juga masyarakat lainnya, karena kegiatan pengabdian masyarakat ini bertujuan untuk menumbuhkan jiwa kewirausahaan dan mengembangkan usaha sampingan bagi para guru SMP Al-Islah Surabaya, dengan begitu apabila para guru ini sudah termotivasi dan berkeinginan untuk membuka/merintis sebuah usaha maka mereka bisa meningkatkan perekonomian mereka sendiri, membuka lapangan pekerjaan, dan juga bisa membantu memajukan perekonomian masyarakat sekitar. Kegiatan pengabdian kepada masyarakat dengan memberikan materi mengenai menumbuhkan jiwa kewirausahaan menjadi jembatan bagi perguruan tinggi khususnya UNUSA dengan masyarakat dalam mentransfer ilmu dan pengetahuan yang sudah luas sehingga dapat langsung dirasakan oleh peserta dari para guru di SMP Al-Islah Surabaya.

\section{DAFTAR PUSTAKA}

Basrowi. (2014). Kewirausahaan untuk Perguruan Tinggi. Bogor: Ghalia Indonesia. Bygrave, and William, D. 1994. The Portable MBA in Entrepreneurship. New York: John Willey \& Sons, Inc.

Drucker, P.F , 1994, Innovation and Entrepreneurhip, New York: Harpercollins Publisher Putra, R. S. (2016). Mengubah Pola Pikir Karyawan Menjadi Pola Pikir Pengusaha Bagi Warga Kecamatan Karangpilang Surabaya: PPM 
Putra, R. S. (2017). Pengelolaan Sumber Daya Manusia Untuk Memulai Usaha Olahan Bandeng di Desa Jenggolo Sidoarjo. Community Development

Ratnasari, W.T. (2009). Perbedaan Tingkat Kecemasan Menghadapi Pensiun antara Pegawai Negeri Sipil yang tidak Mempunyai Pekerjaan Sampingan dan Mempunyai Pekerjaan di Badan Kepegawaian Daerah Kota Ponorogo. Skripsi, tidak diterbitkan. Fakultas psikologi UIN Maulana Malik Ibrahim

Scarborough, N.M. \& T.W. Zimmerer. 2005, Essentials of Entrepreneurship and Small Business Management, Fourth Edition, New Jersey: Prentice-Hal.

Suhartini, Y. (2011). Analisis Faktor-Faktor yang Mempengaruhi Minat Mahasiswa dalam Berwiraswasta. Akmenika UPY Volume 7 , 44-46. 